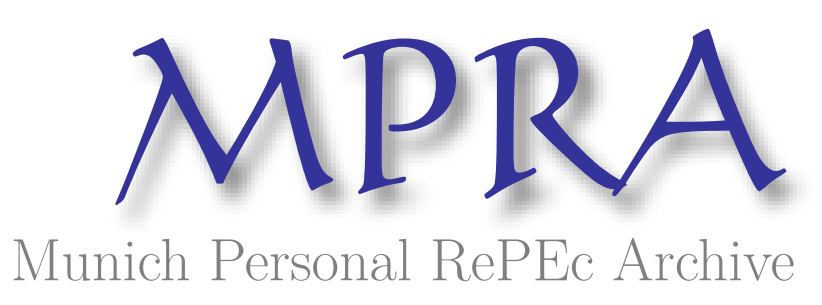

\title{
Wage Differentials in Sri Lanka: The case of a post-conflict country with a free education policy
}

Kumara, Ajantha Sisira

University of Sri Jayewardenepura

2 November 2015

Online at https://mpra.ub.uni-muenchen.de/68068/

MPRA Paper No. 68068, posted 27 Nov 2015 06:28 UTC 


\title{
Wage Differentials in Sri Lanka: The case of a post-conflict country with a free education policy
}

\author{
Ajantha Sisira Kumara \\ Department of Public Administration \\ Faculty of Management Studies and Commerce \\ University of Sri Jayewardenepura \\ Sri Lanka \\ mhasisira@sjp.ac.lk
}

\begin{abstract}
This study analyses wage differentials in Sri Lanka by the individuals' educational attainment. The wage returns to education are estimated by using a combination of the techniques of ordinary least-square, two-stage least-square, sample-selection, and quantile regression on micro-data of the Sri Lanka Labour Force Survey-2013. Therefore, the estimates provided by this study are representative of the entire country and corrected for both the endogeniety and the sample-selection biases. The study concludes that education generates a positive impact on private earning. The results show that one additional year of schooling increases hourly wage rate by $9 \%$ approximately. Also, according to the results, the primary and secondary education reduces income inequality among people whereas the bachelor's-degree University education is a contributor to the income inequality. Further, the results relating to the additional controls reveal that the male, urban, and the public sector employees earn relatively higher wage returns.
\end{abstract}

Keywords: Education; Equality; Household surveys; Instrumental variables; Micro-data; Quantile Regression; Returns; Sample-selection; Sri Lanka; Wage rates

JEL Classifications: I00; I24; I26

\section{Introduction}

The present government of Sri Lanka that was elected in August, 2015 recognizes that the country's "National Human Resources and Employment Policy" needs to urgently address the question of "wages". Particularly, the productivity and the decency of employment are believed to be ensured through a carefully designed wage policy (Secretariat 
for senior ministers: Sri Lanka, 2015). Also, the government believes that the issue of persistent income inequality among individuals may be addressed by carefully formulated wage and education policies where education is treated as a means for equality. For instance, the present government has promised through their election manifesto to allocate $6 \%$ of country's GDP for education in fiscal years ahead since that percentage has thus far been stagnant at 1.8\%-2.0\% of GDP (Central Bank of Sri Lanka, 2011). Even though empirical evidence explaining the relationship between the levels of education and earning is currently available for a number of developing and emerging market countries, such empirical literature is limited for Sri Lanka. Therefore, the present work aims to contribute to the existing literature by analyzing wage differentials in Sri Lanka in terms of level of education and by answering the question of whether different levels of education result in differing returns. Moreover, the study examines whether the Sri Lankan free education policy has been successful in narrowing down the income inequality among people. These research questions are particularly important due to the fact that they provide useful information on educational tracks by guiding individuals and governments towards cost-effective decisions with regard to education (Bettinger and Baker, 2011). Particularly, the rates of return to education would be an indicator of how an individual's educational attainment is rewarded in the labour market of a country. Public and private investment decisions are guided by such evidence and therefore, the studies on education-earning relationships in both developed and developing countries continue to grow (Geetha Rani, 2014).

The case of Sri Lanka would be an interesting one with useful insights to other emerging market countries. One notable exception is that Sri Lanka, a country with a free education system up to the first degree University level, is planning to undertake major reforms in education and wage settlements under the new regime after the three-decade civil war. Unlike many other developing countries, Sri Lanka has achieved a satisfactory level of literacy and school enrolment regardless of many obstacles (World Bank, 2014). The Sri Lankan case sheds some light on how the labour market of a low-income country emerging from a 30-year civil conflict connects rewards to the individuals' educational attainments gained through the country's free education system. Present study considers the situation of post-conflict Sri Lanka where the newly-elected government is in major reconciliation and reconstruction mode. Therefore, this is ideal timing for understanding the role of education in determining wages because, it will enable the intended wage and education policies to better fit equality considerations of the society. To the best of author's knowledge, there is only one study which provides estimates of the impact of education on wages in Sri Lanka at a micro 
level. That is Himaz and Aturupane (2015) which was conducted by using the Sri Lanka Labour Force Survey for the years 1997-2001, 2003-2004, 2006, and 2008. However, neither of those surveys captured information from all the provinces in Sri Lanka and therefore, the estimates were not representative of entire Sri Lanka. Particularly, the data were not available for Northern and Eastern provinces for those years due to the fact that those areas were being directly affected by the civil war during the period when those surveys were conducted. This article attempts to extend the analysis by Himaz and Aturupane (2015) by using the most recent data of the same survey. The survey captured information from entire Sri Lanka including Northern and Eastern provinces, and therefore, the estimates provided by this study are representative of the entire country.

However, this study differs from Himaz and Aturupane's (2015) in terms of the estimation procedure employed. The main issues that any researcher should address when establishing education-earning relations include the endogeniety bias and the sampleselection bias. As observed by Balestra and Backes-Gellner (2013), empirical studies often deal with only one issue at a time. The estimations of this study would be more reliable because, the study addresses both issues simultaneously.

Moreover, one of the main arguments for the free education policy is that equality is promoted by an increased access to education. Accordingly, wage-return for an additional year of schooling for individuals at the top of the wage distribution would be less dramatic than that for individuals at the bottom percentiles of the wage distribution (Jackman and Bynoe, 2014). Therefore, addressing the research question of whether level of education affects individuals differently across the total wage distribution is more important than estimating only the rate of return for education because that type of an analysis provides rich information with regard to equality considerations of education. However, as Wang (2013) noted, the studies analyzing how education affects wage-return over the wage distribution have been rare in the literature. By bridging that research gap, this study attempts to estimate the rate of return for different levels of education for Sri Lankan individuals at different quantiles of the wage distribution. To the best of author's knowledge, this is the first study which uses the Heckit process with instrumental variables and quantile regression properties on an island-wide survey of Sri Lanka.

The rest of the paper is organized as follows: the next section provides a theoretical background. A description of data and their summary statistics are then provided, after that, the estimation procedure and empirical results are discussed. Finally, the paper concludes. 


\section{Theoretical background}

The estimation of wage equation has been one of major concerns of the studies on economics of education and labour economics since the seminal works of Becker (1962) and Mincer (1974). Economists consider spending on education as an investment in an individual's human capital which greatly raises his or her income. Many studies have confirmed that the wage earning of more-educated individuals are relatively higher than that of less-educated individuals even after netting out cost of education. Therefore, wage differentials by individuals' level of educational attainment monetarily motivate people to invest in education. Technically speaking, the Mincer (1974) model assumes that an individual chooses his optimal number of years of schooling to maximize the total present value of future income net of cost of schooling until the retirement. More education is justified if the rate of return to education is greater than the market interest rate.

The most general analytical framework employed in the analyses of private returns to education has been based on this Mincer wage model where log value of wage earning is regressed on years of schooling and years of work experience (Heckman et al., 2005). Accordingly, the basic Mincerian wage earning equation takes the following form:

$$
\ln \left(W_{i}\right)=\beta_{0}+r E_{i}+\beta_{1} X_{i}+\beta_{2} X_{i}^{2}+\varepsilon_{i}
$$

where $W$ is the hourly wage, $\mathrm{E}$ is the years of schooling, $\mathrm{X}$ is the years of experience. The coefficient $r$ can be interpreted as the average rate of return to an extra year of schooling irrespective of the level of education. The experience variable is included as a component of human capital since an individual with higher work experience in a particular employment is likely to earn higher wage rate. Also, to capture any possibility of a quadratic relationship between experience and wage rate, the experience-squared is included. Finally, the random error term $\mathcal{E}$ captures unobserved characteristics.

The Mincer wage equation has been estimated for different countries by using different econometric techniques and different datasets. First, it is always worthwhile looking at the studies which cover a wider range of countries at the same time. For instance, as estimated by Psacharopoulos and Patrinos (2004), both the global and Asian average rate of return to education has been about $10 \%$. The highest rate of return was reported in SubSaharan African region where an additional year of schooling increases earning by $12 \%$ approximately. Also, OECD countries, Middle East countries and European countries have 
reported the lowest rate of return to education (around 7\%). These trends have been recently confirmed by Montenegro and Patrinos (2013). Then, the studies on individual countries with the characteristics similar to Sri Lanka provide hints and directions. Recently, Jackman and Bynoe (2014) estimated the rate of return to education for Barbados, a small state with a free education policy, to be $13.5 \%$ approximately. According to the most recent evidence by Geetha Rani (2014), Indian individuals earn around $8 \%$ as returns to education after controlling for ability, family, social, and religious effects. This rate is around $11 \%$ in Bangladesh (Akanda et al., 2014). The traditional Mincer wage equation has been augmented by authors in different ways depending on the scope of their studies. The literature with regard to such modifications will be discussed under "estimation procedure and results" section where the analytical framework of this paper is developed.

\section{Data and descriptive patterns of variables}

In the empirical analysis, the study uses micro-data from the Sri Lanka Labour Force Survey for the year 2013. This survey is conducted by the Department of Census and Statistics-Sri Lanka on quarterly basis to measure and update the trends of employment, unemployment, and labour force in Sri Lanka. The survey provides micro-data on a wide range of scope covering individuals' demographic profiles, labour force status, employment status, and the structure of earning. This is the most recent version of the survey which covers 25,000 households from all provinces of Sri Lanka. According to the Department of Census and Statistics-Sri Lanka (2014), working-age population consists of all the individuals whose age is 15 years and above. Accordingly, the survey captures information from 58,710 working-age individuals. However, as depicted in Panel A of Table 01, there is only $28.2 \%$ of working-age individuals are involved in wage employments. The majority of the individuals $(78 \%)$ are having secondary level education while on average, $4 \%$ of working-age individuals have never schooled.

Also, on average, $80 \%$ of working-age population is living in rural-Sri Lanka and though there are nine provinces, $24.5 \%$ of working-age population belongs to Western province. Moreover, Panel A of Table 01 further describes the fact that majority of workingage individuals are females, married, and Buddhists. When it comes to employment-sector of wage employees, more than $50 \%$ are employed in private sector whereas about $20 \%$ of wage employees are employed in the government sector. Also, it should be noted that there is a relatively larger informal sector in Sri Lanka which employs approximately $17.4 \%$ of wage employees. 
Panel B of Table 01 provides mean values and standard deviations of continuous variables used in the analysis. Accordingly, on average, a Sri Lankan wage employee earns an hourly wage rate of 100.20 LKR. Also, the mean values of age, years of schooling, and family-effect defined as the average years of schooling of the other family members are 42 , 10, and 8 years, respectively. The variable "family-effect" is replaced with the district average of years of schooling of individuals if a particular household consists of only one member. In this study, the human capital variable "work experience" is proxied by age of individuals as the survey does not directly provide work experience for individuals. Unless otherwise mentioned, in the estimation procedure, the study uses sample weights provided by the survey to inflate the data so that the estimates represent the entire Sri Lankan population.

\section{Estimation procedure and results}

This study extends the conventional Mincerian wage equation by taking several additional covariates into account. Initially, the study considers the restricted sample that is only the wage-employees to provide a glimpse of wage rate differentials across various covariates considered. A line of studies has already proven that there is inequality in wage rates by gender in Sri Lanka (Ajwad and Kurukulasuriya, 2002; Himaz and Aturupane, 2015; Weerahewa, 2002). Existing empirical evidence indicates that wage rates for male individuals are relatively higher than that for their female counterparts. This is clearly visible from Figure 01 which demonstrates that male individuals receive significantly higher wage rate than female individuals across all the levels of educational attainment considered. Accordingly, the traditional Mincer wage equation is augmented by incorporating gender of individuals to capture the difference between wage rates of males and females.

Also, geography of individuals plays an important role in determining wage earning in any context. Previous studies with regard to Sri Lanka have concluded that returns to education are relatively higher in urban areas than that in rural areas (Aturupane, 1993 and Himaz and Aturupane, 2011). However, living sector of people in Sri Lanka is tripartite including, urban, rural, and estate sectors. The estate sector is a special sector which is only observable in Sri Lanka and consisting of all plantations which are 20 acres or more in extent with 10 or more resident labourers. Of the total estate population, 75.1\% is Indian Tamil. As depicted in Figure 02, average hourly wage rate has been significantly higher in urban sector than that in rural and estate sectors across all the levels of educational attainment. Further, the least average hourly wage has been reported in the estate sector. Therefore, the study included three living sector dummies in the Mincer wage equation to account for differences 
in wage rates in urban, rural, and estate sectors in Sri Lanka. Moreover, the study included a dummy variable to capture the differences in wage returns in Western province and other provinces. Western province is the most developed province in Sri Lanka in terms of GDP contribution and employment creation. As depicted in Figure 03, average hourly wage rate in Western province has been substantially higher compared to other provinces.

The employment sector of individuals in terms of government, semi-government, and formal private sector contributes to determine earnings of wage employees. For instance, Rahona-Lopez et al. (2015) provide evidence to prove that public sector workers tend to earn higher wages than private employees in Spain due to favorable productivity characteristics of public sector workers. Also, a differential in wage adjustment between public and private sectors has been explored by Chistopoulou and Monastiriotis (2015) for Greece. Nevertheless, wage differentials have not been analyzed much in terms of individuals' employment sector for Sri Lanka. Figure 04 is a snapshot of wage rate differentials across employment sectors. Accordingly, for the individuals with primary and secondary level of education as the maximum attainment, the government sector provides a higher wage rate than the other sectors. In contrast, for the individuals with higher educational attainment than secondary level, private sector offers a higher wage rate on average. Accordingly, the augmented Mincer equation used in this paper can be written as follows:

$$
\begin{aligned}
\ln \left(W_{i}\right)= & \beta_{0}+r E_{i}+\beta_{1} X_{i}+\beta_{2} X_{i}^{2}+\beta_{3} \text { Male }_{i}+\beta_{4} \text { Urban }_{i}+\beta_{5} \text { Rural }_{i}+ \\
& \beta_{6} \text { Western }_{i}+\beta_{7} \text { Government }_{i}+\beta_{8} \text { Semi government }_{i}+\beta_{9}{\text { Pr } \text { ivate }_{i}+\varepsilon_{i}}
\end{aligned}
$$

where Male is a binary variable which takes the value 0 if the individual is female and 1 if the individual is male. The variables Urban and Rural are living-sector dummies, taking on a value of 1 if the individual is living in urban sector and rural sector, respectively. The binary variable Western takes 1 if the individual is living in Western province of Sri Lanka. Finally, Government, Semi government, and Private are also dummy variables to represent the individual's employment sector.

It is generally accepted phenomena that rates of private return to education are not constant across different levels of education. For instance, the rate of private return to education for a person only with secondary level of attainment is different from that for a person with a postgraduate degree. Accordingly, it is important for researchers to provide information on the rate of return to education for different levels of educational attainment. 
Therefore, this study estimates the equation 2 by different levels of education by rewriting it as follows:

$$
\begin{aligned}
\ln \left(W_{i}\right)= & \beta_{0}+\sum_{t=1}^{4} r_{t} E_{t i}+\beta_{1} X_{i}+\beta_{2} X_{i}{ }^{2}+\beta_{3} \text { Male }_{i}+\beta_{4} \text { Urban }_{i}+\beta_{5} \text { Rural }_{i}+ \\
& \beta_{6} \text { Western }_{i}+\beta_{7} \text { Government }_{i}+\beta_{8}{\text { Semi } \text { government }_{i}+\beta_{9} \text { Private }}_{i}+\varepsilon_{i}
\end{aligned}
$$

where $\mathrm{t}$ denotes the level of educational attainment: when $\mathrm{t}=1$, the dichotomous variable $E_{t i}$ takes 1 for individuals with primary level of education (from grade 1 to grade 5 of school education); when $\mathrm{t}=2$, the variable $E_{t i}$ takes 1 for individuals with secondary level of education (from grade 6 to advanced level of school education); when $\mathrm{t}=3$, the variable $E_{t i}$ takes 1 for individuals with a bachelor's degree, and finally, when $\mathrm{t}=4$, the $E_{t i}$ takes 1 for individuals with postgraduate qualification. The reference category is the hourly wage rate for a person who has never schooled.

Estimates of the rate of private return of education by different levels of education are reported in the third column of Table 02. It is clear from the results that after controlling for experience, living sector, employment sector, gender, and the impact of professional training, the individuals with primary education as the maximum educational attainment earn $1.5 \%$ (on average) more than the individuals who have never schooled. Also, the individuals with secondary level of schooling, bachelor's degrees, and postgraduate degrees as their maximum educational attainment earn $24 \%, 65 \%$, and $82 \%$ (on average) more than those who have never schooled, respectively. However, these estimates are gross computations of rate of private return to education obtained from a multiple regression model. The multiple regression models allow computing effects of covariates in the mean of the conditional distribution of wages depending on restrictive assumptions about the parametric distribution of errors. Therefore, in the next sections, the study provides more consistent and unbiased estimates by relaxing such strictly imposed assumptions.

\section{Results corrected for the endogeniety bias}

In estimating the rate of return to education, one of main issues that should be addressed is the endogeniety of educational attainment variables. The endogeniety emerges as an issue if unobserved variables mainly including "ability" of individuals are correlated with both levels of educational attainment and the error term. A bias created by the issue of endogeniety can either be positive or negative. If individuals with relatively higher level of 
"ability" are likely to pursue more years of schooling, then it creates a positive bias. However, the bias could also be negative if individuals with higher "ability" tend to join the labour force to earn higher wage by leaving school early. The most common approach to overcome the endogeniety problem is employing instrumental variable (IV) regressions (Angrist and Krueger, 1991; Card, 1999; Trostel et al., 2002). Hence, equation 2 is reestimated using two instrumental variables for the endogenous variable "years of schooling". Those two instruments are "birth-month effect" and "family-effect" of individuals.

First, this study searches for a potential of employing month of birth of individuals as an instrumental variable for their years of schooling. A line of studies has produced empirical evidence from different country-contexts to prove that children born later in the academic year have relatively lower educational attainment than those who are born earlier in the year (Black et al., 2011; Datar, 2006; Fredriksson and Ockert, 2014; Puhani and Weber, 2007). Though there are multiple drivers of birth-month-effect on educational attainment, no single driver or a combination of drivers has conclusively been established to date (Campbell, 2013). The theories established on such driving forces of birth-month-effect on educational attainment span the biological and social sciences. Biological theories highlight that birthmonth-related-biology of an individual can have a significant impact on his or her educational attainment (Sharp et al., 2009). Socio-structural theories emphasize on the differentials of driving forces in relation to the administration of the education system of a country. These driving forces mainly include differentials in absolute age and years of schooling determined by the month of birth of an individual (Crawford et al., 2011). Moreover, psycho-social theories conclude that problems in relation to academic performance are particular for younger children in a class due to the relative immaturity of them at the point of entry to the primary level. In other words, younger children in a class exhibit lack of parity in social, emotional, and cognitive school readiness being disadvantaged in class rooms (Sharp et al., 2009).

In Sri Lanka, schools' academic year begins in January. Children who have completed five years of age by $31^{\text {st }}$ January are eligible to join grade one. The compulsory schooling age for Sri Lankan children has been enforced to be 5-14 years of age as per the education reforms implemented in 1997 (UNICEF-Sri Lanka, 2013). Children who are born earlier months in the calendar-year are relatively older at the point of entry to the primary schools than those who are born late in the year. As a result, at the end of the academic year, a particular grade consists of a substantial number of students who are older than the stipulated official age relevant to that grade. It is evident from the data that Sri Lankan individuals who 
are born in earlier months have relatively a larger number of years of schooling than those who are born in late in the year. For instance, those who were born in the first quarter of the year reported the highest average years of schooling which is approximately 9.7 years. Also, those who were born in the third and the fourth quarters reported relatively lower averages (9.3 years). Therefore, there may be birth-month-effect in educational attainment of Sri Lankan individuals, and the birth-quarter of individuals may have a potential to be used as an instrumental variable for years of schooling in subsequent analyses.

Second, the study attempts to check the potential of another instrumental variable, "family-effect", for years of schooling of Sri Lankan individuals. The human capital theory predicts that children from well-off families in terms of wealth and educational background tend to have a larger number of years of schooling. A study by Ranasinghe and Hartog (2002) confirms that, in Sri Lanka, students from educationally sound families are likely to stay in schools for a longer period and to have a higher potential in passing the ordinary-level examination. Hence, this study uses "average years of schooling of other family members" to capture the family-effect and checks its potential to be used as an instrumental variable for years of schooling of the relevant individual. According to the data, there is a significantly positive correlation (correlation coefficient is +0.0561 and significant at $5 \%$ error level) between the family-effect and the years of schooling of Sri Lankan individuals.

The study re-estimates equation 2 using two-stage-least-square (2SLS) technique to address the problem of endogeniety and records the results in fourth column of Table 02 . The Hausman test is used to test whether the variable "years of schooling" is endogenous. The null hypothesis of the test is the variable "years of schooling" of individuals is exogenous. However, the smaller $\mathrm{P}$-value of the test statistics $(\mathrm{P}=0.0006)$ indicates that the null hypothesis can be rejected confirming that the variable "years of schooling" is endogenous. Next, the validity of instrumental variables is tested using the Sargan's test where the null hypothesis is that all instruments are valid. According to the P-value of the Sargan's score $(\mathrm{P}=0.3136)$, the study does not reject the null hypothesis and concludes that overidentification restriction is valid.

There is an issue of instruments if they are weakly correlated with the endogenous variable. In such cases, the usual 2SLS estimators are biased toward the OLS estimator. Therefore, before proceeding, it is important to determine whether the instruments used are weak. Since the study has only one endogenous variable, the F-test of the first-stage regression can be used to check for weakness of instruments. According to Stock et al. (2002), the F-statistics should exceed 10 for 2SLS-based inference to be reliable. As depicted 
in Table 02, the F-statistics for the first-stage regression is 474.055 and it is statistically significant even at $1 \%$ error level. This confirms that the instruments used in this study are not weak. Moreover, Stock and Yogo (2005) provide useful rules of thumb with regard to the weakness of instruments based on Cragg and Donald (1993) statistics. In this study, the Cragg and Donald's statistics and the F-statistics are identical because, there is one endogenous variable. The last row of Table 02 includes the critical value for the test that the instruments are weak depending on the bias of the 2SLS estimator relative to the bias of the OLS estimator. The Cragg and Donald's test statistics is well above the critical value. This confirms the relative bias that the 2SLS estimator of the study tolerates is no greater than 5\% and in that sense, the instruments used are not weak.

As shown in Table 02, there is a considerable difference between OLS and 2SLS estimators for the variable "years of schooling". Approximately, the rate of return to an additional year of schooling is $8 \%$ on average after accounting for the endogeniety bias. Therefore, the endogeniety bias has resulted in under-estimating the rate of return to education for Sri Lankan individuals by two percentage points approximately. Thus, the endogeniety bias is negative and it indicates that unobserved characteristics of individuals including "ability" push students to leave the process of formal education early and to join the labour market to earn higher wages.

\section{Results corrected for the sample selection bias}

Further, the study extends to address the issue of the sample selection bias. The estimation results discussed thus far may be subject to sample selection biases because, the study has employed a restricted sample. As a consequence, our estimations might be inconsistent with the population parameters due to the fact that individuals with observed wages (wage employees) are systematically different from individuals without observed wages (non-wage individuals). Hence, to address this probable sample selection bias, the full sample is taken into consideration to estimate the Heckman (1979) two-stage model. According to the Heckit process, first, a selection equation (Probit model) is estimated to compute the probability of being a wage employee using the total sample as follows:

$$
\operatorname{Pr}\left(y_{i}=1 \mid X_{i}\right)=\Phi\left(X_{i} \beta+\varepsilon_{i}\right)
$$


where $y_{i}$ is a binary variable which takes 1 if the individual is a wage-employee and 0 otherwise; $X_{i}$ is the vector of all explanatory variables used for the probit model; and $\Phi()$ is cumulative density function. It should be noted that religion and marital status of individuals are considered as covariates in the probit model as certain previous studies have already confirmed that those variables have an impact on the probability of being a wage employee. Then, the study uses the results obtained from the probit model to compute the inverse Mills' ratio $(\lambda)$. This inverse Mills' ratio is included in the wage equation at the second stage to correct sample selection bias according to the following specifications:

$$
\begin{aligned}
& E\left[\ln \left(W_{i}\right) \mid W_{i}>0, X_{i}\right]=X_{i} \beta+\sigma \lambda_{i}+v_{i} \text { if } y_{i}=1 \\
& \ln \left(W_{i}\right) \text { not observed, if } y_{i}=0 \\
& \text { Inverse Mills' Ratio : } \lambda_{i}\left(X_{i} \beta\right)=\frac{\phi\left(X_{i} \beta / \sigma\right)}{\Phi\left(X_{i} \beta / \sigma\right)}
\end{aligned}
$$

where $\phi()$ is the standard normal probability density function.

The wage equation can be consistently estimated using OLS or 2SLS, if the error terms $\left(\varepsilon_{i}, v_{i}\right)$ are uncorrelated. However, the sample selection biases are inevitable if error terms are correlated. An indicator of the significance of the correlation between $\varepsilon_{i}$ and $v_{i}$ is given by the inverse Mills' ratio calculated in equation 6. The results obtained via Heckit process are recorded in Table 03 and the study estimates equation 5 using OLS and 2SLS methods to correct the probable endogeniety bias as well.

As shown in Table 03, the estimate of the inverse Mills' ratio is statistically significant in both OLS and 2SLS estimations, confirming that unobserved factors of the selection equation and the wage equation are correlated. In other words, the statistically significant inverse Mills' ratio in both cases (OLS and 2SLS) confirms the presence of sample selection bias and it therefore, justifies the use of the Heckman procedure. The results recorded in the last column of Table 03 are the estimates obtained via 2SLS procedure where the variables "birth-quarter" and "family-effect" have been used as instrumental variables for the endogenous variable "years of schooling". The statistically significant Hausman test score confirms that the variable "years of schooling" is endogenous whereas the statistically insignificant Sargan score confirms that the instruments used are valid. Also, the F-test for 
the first-stage regression and the Stock and Yogo's (2005) test for weakness of the instruments robustly confirm that the instruments are not weak. Estimates from the selection equation conclude that the individuals living in urban and rural sectors are less likely to participate in wage employments than their counterparts in estate sector. Also, Muslim individuals are less likely to be wage employees compared to individuals in other religions. Moreover, married individuals with higher level of education and professional training are exhibiting significantly higher probabilities of being wage employees.

The equation of particular interest is the wage equation. The results suggest that even after accounting for sample selection bias and endogeniety bias, an extra year of schooling increases hourly wage rate by $9 \%$ being other variables unchanged. Himaz and Aturupane's (2015) study has obtained the same rate of private return to education for Sri Lanka using cross sectional regression on the individual data from the Sri Lanka Labour Force Survey. Nevertheless, their pseudo-panel approach has under-estimated that rate by four percentage points. According to a recently conducted study by Montenegro and Patrinos (2013), the global average of the rate of return to extra year of schooling is approximately $10 \%$ whereas the same number for the South Asian region where Sri Lanka belongs to is $7 \%$. Thus, the rate of return to education for Sri Lankan individuals falls between its global average and regional average.

Moreover, the comparison of OLS and 2SLS estimates even after accounting for the sample selection bias demonstrates that the endogeniety creates a negative bias for the estimate of years of schooling. Preciously speaking, the rate of return to education has reduced approximately by 6 percentage points due to that bias. Therefore, it is evident that unobserved factors including individuals' "ability" push them to leave school early and to join the labour market to earn higher wage rates. For instance, a study by UNICEF-Sri Lanka (2013) reveals that there are only $51.4 \%$ of children whose age is 16 years in schools. Also, of children whose age is 17 years, only $39.9 \%$ are in schools. Considerably higher dropout rates are not merely because of their inability to continue formal education, but largely because of poverty, higher opportunity cost of education, unfavorable supply-side factors such as poor-quality educational infrastructure facilities available in Sri Lankan schools, and certain cultural factors (Arunatilake, 2006 and Pallegedara, 2012). The similar trends of downwards endogeniety bias have been observed by Angrist and Krueger (1991), Card (1999), Land (1993), and Trostel et al. (2002) in their studies on education-earning relations.

It should be noted that there is a lack of reliable information with regard to early school leavers in Sri Lanka, their abilities, labour market positions, and wages (Hettige et al., 
2004). However, several authors have pointed out some advantageous conditions of early school leavers in progressing in the local and international labour markets. As discussed by Kariyawasam (2008), schools provide students with more white-collar-job-oriented education and fail to provide them with useful capabilities which are in higher demand in the rural economy. Hence, it seems as if early school leavers have more opportunities to enjoy a variety of choices for winning lucrative opportunities in the labour market. Also, as highlighted by Hettige et al. (2004), motivation to learn foreign languages including English and to acquire technology-oriented vocational training is apparently higher for early school leavers than that for those in schools. This is because, early school leavers who are already employed somewhere have a better understanding of the requirements of the labour market.

Moreover, after accounting for the sample-selection bias, equation 3 is re-estimated by employing quantile regression technique with bootstrapped errors which does not impose distributional assumptions of errors. Also, quantile regression technique allows estimating the effects of explanatory variables on different points of the wage distribution. For instance, the study will be able to explore whether wage returns to different levels of education differ for persons in the upper quantile of the wage distribution than those in the lower quantiles. The quantile regression technique controls for individual heterogeneity as well because, it estimates private returns to education on different quantile points of the wage distribution allowing heterogeneity through different intercepts and slopes which are specific to particular quantile points of the wage distribution. Accordingly, equation 3 is re-estimated on the basis of the econometrics specifications of quantile regression technique. The linear mode of a quantile regression model is written as:

$$
y_{i}=x_{i} \beta(\theta)+\varepsilon_{\theta i}, i=1 \ldots . . N, \theta \in(0,1)
$$

where $\mathrm{N}$ is the sample size, $y_{i}$ is the dependent variable, $x_{i}$ is a vector of explanatory variables, $\beta(\theta)$ is the vector of estimated coefficients for $\theta^{\text {th }}$ percentile, and $\varepsilon_{\theta i}$ is the error term. The random error term is distributed so that $Q_{\theta}\left(\varepsilon_{\theta i} \mid x_{i}\right)=0$.

Therefore, $Q_{\theta}\left(y_{i} \mid x_{i}\right)=x_{i} \beta(\theta), \theta \in(0,1)$. This formulation implies that the marginal effects of explanatory variables differ across quantiles. The vector of estimated coefficients for a given $\theta$ is obtained by minimizing the following function of the weighted sum of the absolute value of the error terms:

$$
\hat{\beta}(\theta)=\arg \min \frac{1}{N}\left\{\sum_{i: y_{i}>x_{i} \beta} \theta\left|y_{i}-x_{i} \beta\right|+\sum_{i: y_{i}<x_{i} \beta}(1-\theta)\left|y_{i}-x_{i} \beta\right|\right\}
$$


Accordingly, the wage equation is re-written as follows to capture the properties of quantile regression model:

$$
\begin{aligned}
Q_{\theta}\left[\ln \left(W_{i}\right)\right]= & \beta_{0}(\theta)+\sum_{i=1}^{4} r_{t}(\theta) E_{t i}+\beta_{1}(\theta) X_{i}+\beta_{2}(\theta) X_{i}^{2}+\beta_{3}(\theta) \text { Male }_{i}+\beta_{4}(\theta) \text { Urban }_{i}+ \\
& \beta_{5}(\theta) \text { Rural }_{i}+\beta_{6}(\theta) \text { Western }_{i}+\beta_{7}(\theta) \text { Government }_{i}+\beta_{8}(\theta){\text { Semi } \text { government }_{i}+}+ \\
& \beta_{9}(\theta) \text { Private }_{i}+\sigma \lambda_{i}(\theta)+\varepsilon_{i}(\theta)
\end{aligned}
$$

where $\lambda_{i}$ is the inverse Mills' ratio obtained after the selection equation.

Generally, an attractive way of presenting quantile regression results is via a graphical display of coefficients of interest and their respective confidence intervals (Cameron and Trivedi, 2010). Accordingly, Figure 05 presents the quantile-specific coefficients for the $10^{\text {th }}$ to $90^{\text {th }}$ quantiles along with the OLS coefficient for each level of educational attainment and their confidence intervals at 5\% error level. First of all, from the figure, it is clear that individuals with higher level of educational attainments earn relatively higher wage rates than the others at all the quantile points of the wage distribution. As depicted in Figure 05, private returns to education vary slightly across different quantile points of the wage distribution for individuals whose maximum level of education is primary level or secondary level. Particularly, the results show that the wage implication for the individuals at the top of the wage distribution is less dramatic than those at the bottom quantiles if their maximum educational attainment is primary or secondary level of schooling. Therefore, there is withingroup wage equality among individuals with primary and secondary level of schooling as their maximum educational attainment.

However, the wage returns are substantially greater for bachelor's degree holders at the top of the wage distribution when compared to the similarly educated individuals at the bottom of the wage distribution. Accordingly, it is evident that the University education for bachelor's degrees in Sri Lanka is a contributor to within-group wage inequality. In other words, there is a severe variation in the wage rate for bachelor's degree holders in Sri Lanka depending on his or her position in the wage distribution. The bachelor's degree holders at the top of the wage distribution earn higher wage rates compared to those at the bottom of the distribution. Wage returns over quantile distribution of wages for individuals whose maximum educational attainment is postgraduate level takes "U-shape". Therefore, as depicted in Figure 05, individuals at the top of the wage distribution and those at the bottom 
of the wage distribution earn approximately the same wage returns if their maximum educational attainment is postgraduate qualification.

According to all the models estimated, the other human capital variables such as experience and professional training are found to be significant determinants of wage rates. Particularly, the marginal effects of professional training on hourly wage rates are substantially high across all the estimation methods. Also, as depicted in Figure 05, the rate of returns to professional training is relatively higher for individuals at the top of the wage distribution. The rate of return to an additional year of experience remains less than $1 \%$ for all the models estimated. As predicted priori, the marginal effect of experience-squared term is negative and statistically significant across all the estimation methods, confirming that there is a non-linear (quadratic) relationship between work experience and earning. Preciously speaking, the returns to work experience exhibit a parabolic shape in which the returns are increasing as work experience increases and maximized somewhere in midlife.

\section{Results emanating from the other control variables}

It is worth highlighting certain results stemming from the other control variables. Estimates from the alternative models robustly confirm that males' hourly wage rate is significantly higher than females' rate. This further confirms the findings with regard to Sri Lanka by Ajwad and Kurukulasuriya (2002). Also, the results robustly conclude that individuals living in urban sector and Western province earn significantly higher hourly wage rates. As described by the quantile regression estimates, individuals at the top of the wage rate distribution are likely to enjoy substantially higher wage rates as a result of being in urban sector and Westerns province in Sri Lanka. This conclusion justifies the current Sri Lanka's higher rate of internal migration from rural to urban areas as well as from other provinces to Western province.

Moreover, the wage differentials in Sri Lanka are discussed in terms of employment sectors: government sector, semi-government sector, and private sector. According to the results, government sector and semi-government sector provide significantly higher hourly wage rates for individuals. In most of the cases, hourly wage rate offered by the Sri Lankan private sector is significantly lower. There might be several reasons why these trends happen in Sri Lanka. Generally, the process of wage determination in the government sector depends more on social and political pressures than on market sources where the governments tend to use their monopolistic power to establish wage settlements for their employees (Christopoulou and Monastiriotis, 2015). 


\section{Concluding remarks}

This study provides a brief analysis of the private return to education in post-conflict Sri Lanka. All the analyses have been conducted at the micro level using the data available from the Sri Lanka Labour Force Survey-2013. The study confirms that the education imposes a positive impact on hourly wage rate of Sri Lankan individuals. On average, an additional year of schooling increases hourly wage rate by $9 \%$ after controlling for the endogeniety and the sample-selection biases. Therefore, any policy which promotes curtailing the educational facilities would reduce these benefits.

Furthermore, the results hint at the negative (downwards) endogeniety bias. Accordingly, unobserved factors promote individuals to leave schools early and to earn higher wage rates by joining the labour force. There may be many reasons why this is possible in Sri Lanka. Since exploring such reasons is beyond the scope of this study, a future study should look at the problem carefully by considering detailed profiles of the early school leavers in Sri Lanka. However, according to Card (1999) and Lang (1993), OLS estimates of the coefficients of wage equation are biased downwards due to the fact that the option of low levels of schooling is chosen by individuals with higher discount rates expecting higher marginal rates of return.

The quantile regression results of this study confirm that the rates of return to primary and secondary education are higher for those at the bottom of the wage-income distribution. This warrants further investment in primary and secondary school education, because more investment in primary and secondary education will lead to a decline in income inequality of the country. Therefore, by expanding educational opportunities in primary and secondary school education, less-able individuals could be made better-off as the rates of return to school education are higher for that category of individuals. In contrast, the rates of return to first-degree University education are higher for those at the top of the wage distribution. Therefore, continuing the free education policy for the first-degree University education in the way it is currently being implemented will lead to an increase in income inequality. This has a strong policy implication for the University education policy of Sri Lanka. A policy for the first-degree University education which will make less-able individuals better-off is highly warranted for Sri Lanka.

Also, the results stemming from the other control variables conclude that wage rates in Sri Lanka are both gender- and location-biased. Particularly, the results imply policies to remove disadvantageous conditions for female employees and employees living in the estate sector. Also, the results imply policies to restructure the wage settlements in Sri Lankan 
private sector as the return to education in private sector is relatively low. The laws on minimum wages, working hours, and wage rate increments would rectify certain disadvantageous conditions of the wage settlements in Sri Lankan private sector.

The conclusions made by this paper are subject to a number of limitations. First, the study does not provide an analysis of the dynamics of rates of return to education. An analysis of the dynamics will explain how returns to schooling have changed over time. The OLS and Heckman selection estimations are applicable in such an analysis as Doan and Gibson (2012) have used them for Vietnam. Second, the study does not provide an international comparison. Third, this study has considered bachelor's and postgraduate degrees as a whole. Therefore, rates of return to those categories of educational attainments are just a glimpse. To have a detailed picture, one should examine the rates of return to undergraduate and postgraduate degree holders in different fields of studies (See Pinitjitsamut, 2012).

\section{References}

Ajwad, M.I. and Kurukulasuriya, P. (2002) 'Ethnic and gender wage disparities in Sri Lanka', Policy research working paper, No. 2859, The World Bank.

Akanda, A.S., Khanam, M., Shafiullah, A.Z. (2014) 'Determinants of Earnings and Selection into Labor Market by Controlling Selection Bias in Bangladesh', Dhaka University Journal of Science, Vol. 62 No. 1, pp.11-16.

Angrist, J. D. and Krueger, A.B. (1991) 'Does compulsory school attendance affect schooling and earnings?', The Quarterly Journal of Economics, Vol.106 No.4, pp.979-1014.

Arunatilake, N. (2006) 'Education participation in Sri Lanka-Why all are not in school', International Journal of Educational Research, Vol.45 No.3, pp. 137-152.

Aturupane, H. (1993) Is education beneficial? A microeconomic analysis of the impact of education on economic welfare in a developing country $\mathrm{PhD}$ dissertation, Cambridge University, UK.

Balestra, S. and Backes-Gellner, U. (2013) 'Heterogeneous returns to education over wage distribution: Who profits the most', Working paper, No. 91, University of Zurich, Switzerland.

Becker, G. (1962) 'Investment in human capital: a theoretical analysis', Journal of Political Economy, Vol.70 No.5, pp. 9-49. 
Bettinger, E., and Baker, R. (2011) 'The effects of student coaching in college: An evaluation of a randomized experiment in student mentoring', NBER Working Paper, No. 16881, National Bureau of Economic Research, New York.

Black, S., Devereux, P., Salvanes, K. (2011) 'Too young to leave the nest?: the effects of school starting age', The Review of Economics and Statistics, Vol. 93 No. 2, pp. 455467.

Cameron, A.C. and Trivedi. P.K. (2010) Microeconometrics using Stata, Chapter 7: Quantile regression, Stata Press, Texas.

Campbell, T. (2013) In-school ability grouping and the month of birth effect: Preliminary evidence from the millennium cohort study, Centre for longitudinal studies, University of London.

Card, D. (1999) The causal effect of education on earnings, In Ashenfelter, O., Card, D. (Eds.), Handbook of Labour Economics, Vol. 3b, North Holland, Amsterdam.

Central Bank of Sri Lanka (2011) Annual Report, Colombo.

Christopoulou, R. and Monastiriotis, V. (2015) 'Public-private wage duality during the Greek crisis', Oxford Economic Papers, gpv 054.

Crawford, C., Dearden, L., Greaves, E. (2011) Does when you are born matter? The impact of month of birth on children's cognitive and non-cognitive skills in England. The Institute for Fiscal Studies. http://www.ifs.org.uk/bns/bn122.pdf (Accessed 17 October 2015).

Cragg, J. G., and Donald, S.G. (1993) 'Testing identifiability and specification in instrumental variable models', Econometric Theory, Vol. 9 No. 2, pp. 222-240.

Datar, A. (2006) ‘Does delaying kindergarten entrance give children a head start?' Economics of Education Review, Vol. 25 No.1, pp. 43-62.

Department of Census and Statistics-Sri Lanka (2014) Sri Lanka labour force survey-2013-

Final report, Colombo.

Doan, T. and Gibson, J. (2012) 'Return to education in Vietnam during the recent transformation', International Journal of Education, Economics and Development, Vol.3 No.4, pp. 314-329.

Fredriksson, P. and Ockert, B. (2014) 'Life-cycle effects of age at school start', The Economic Journal, Vol. 117, No. 518, pp. 399-421.

Geetha Rani, P. (2014) 'Disparities in earnings and education in India', Cogent Economics and Finance, 2:941510 [online]. http://dx.doi.org/10.1080/23322039.2014.941510 (Accessed 5 August 2015). 
Heckman, J.J. (1979) 'Sample selection bias as a specification error', Econometrica, Vol. 47, No. 1, pp.153-161.

Heckman, J.J., Lochner,L. and Todd, P. (2005) 'Earnings functions, rate of return, and treatment effects: The Mincer equation and beyond', Working Paper, No. 11544, National Bureau of Economic Research, New York.

Hettige, S.T., Mayer, M., Salih, M. (2004) School-to-work transition of youth in Sri Lanka. http://www.ilo.org/wcmsp5/groups/public/@ed_emp/@emp_elm/documents/publicatio n/wcms_114297.pdf (Accessed 16 September 2015).

Himaz, R. and Aturupane, H. (2015) 'Returns to education in Sri Lanka: a pseudo-panel approach', Education Economics, (ahead-of-print), pp.1-12.

Himaz, R., and Aturupane H. (2011) 'Education and household welfare in Sri Lanka from 1985 to 2007 ', Working paper, No. 527, University of Oxford.

Jackman, M. and Bynoe, R. (2014) 'Wages, Wage Inequality, and Education: The case of a Microstate with a "Free Education for All" Policy', International Journal of Public Administration, Vol. 37 No. 12, pp. 866-874.

Kariyawasam,T. (2008) The problems of school leavers.

http://www.srilankaguardian.org/2008/02/problems-of-school-leavers.html (Accessed 22 October, 2015).

Lang, K. (1993) Ability bias, discount rate bias, and the return to education. Mimeo, Boston University.

Mincer, J. (1974) Schooling, experience, and earnings, National Bureau of Economic Research, New York.

Montenegro, C.E. and Patrinos, H.A. (2013) Returns to schooling around the world, World Development Report-2013

Pallegedara A. (2012) 'Demand for private tutoring in a free education country: The case of Sri Lanka', International Journal of Education, Economics and Development, Vol.3 No.4, pp. 375-393.

Pinitjitsamut, M. (2012) 'An estimation of lifetime earnings and return on undergraduate education investment for different fields: a case of Thailand', International Journal of Education, Economics and Development, Vol.3 No.2, pp. 149-163.

Psacharopoulos, G. and Patrinos, H. (2004) 'Returns to investment in education: A further update', Education Economics, Vol.12 No.2, pp. 111-134. 
Puhani, P. and Weber, A. (2007) 'Does the early bird catch the worm?: instrumental variable estimates of early educational effects of age of school entry in Germany', Empirical Economics, Vol. 32 No. 2-3, pp. 359-386.

Rahona-Lopez, M., Murillo-Huertas, I.P., and Salinas-Jiménez, M.M. (2015) 'Wage differentials by sector and gender: a quantile analysis for the Spanish case', Journal of Economic Policy Reform, (ahead-of-print), pp.1-19.

Ranasinghe, A. and Hartog, T. (2002) 'Free-education in Sri Lanka: Does it eliminate the family effect?', Economics of Education Review, Vol.21 No. 6, pp. 623-633.

Secretariat for senior ministers: Sri Lanka (2015) National Human Resources and Employment Policy-Sri Lanka, Colombo.

http://www.nhrep.gov.lk/index.php?option=com_content\&view=article\&id=114\&Ite mid=59\&lang=en (Accessed 14 August 2015)

Sharp, C., George, N., Sargent, C., O'Donnell, S., Heron, M. (2009) The influence of relative age on learner attainment and development. National Foundation for Educational Research. http://www.inca.org.uk/Relative_Age_Review_February_2009.pdf (Accessed 17 October 2015).

Stock, J. H., Wright,J. H., Yogo, M. (2002) 'A survey of weak instruments and weak identification in generalized method of moments', Journal of Business and Economic Statistics, Vol. 20 No. 4, pp. 518-529.

Stock, J. H., and Yogo, M. (2005) Testing for weak instruments in linear IV regression, In Identification and Inference for Econometric Models: Essays in Honor of Thomas Rothenberg, (Eds.) D. W. K. Andrews and J. H. Stock, 80-108. New York: Cambridge University Press.

Trostel, P., Walker, I., Woolley, P. (2002) 'Estimates of the economic return to schooling for 28 countries', Labour Economics, Vol. 9 No. 1, pp.1-16.

UNICEF-Sri Lanka (2013), Out-of-School Children in Sri Lanka:Country Study, A country report, Colombo.

Wang, L. (2013) 'How does education affect the earnings distribution in urban China?' Oxford Bulletin of Economics and Statistics, Vol. 75 No. 3, pp. 435-454.

Weerahewa, J. (2002) 'Globalization and male-female inequality in Sri Lanka: Short run and long run impacts', Globalization and poverty programme, DFID.

World Bank (2014) Sri Lanka Overview. http://www.worldbank.org/en/country/srilanka/overview\#1 (Accessed 5 August 2015). 
Figure 01: Average Hourly Wage by Maximum Educational Attainment and Gender

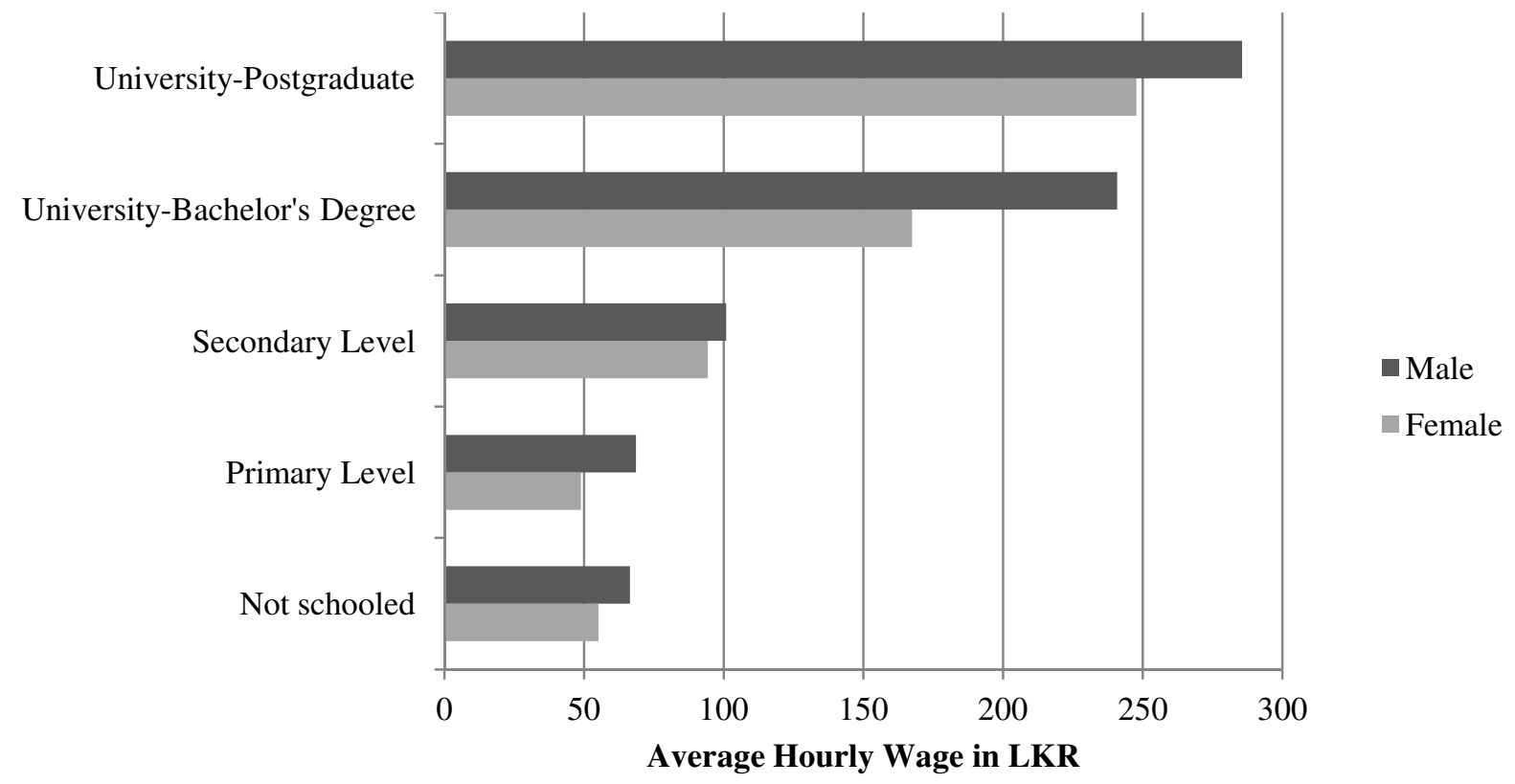

Source: Own calculation based on Sri Lanka Labour Force Survey-2013

Note: Hourly wage rate differentials across different levels of education are statistically significant at 5\% error level within each gender group and between two gender groups.

Figure 02: Average Hourly Wage by Maximum Educational Attainment and Living Sector

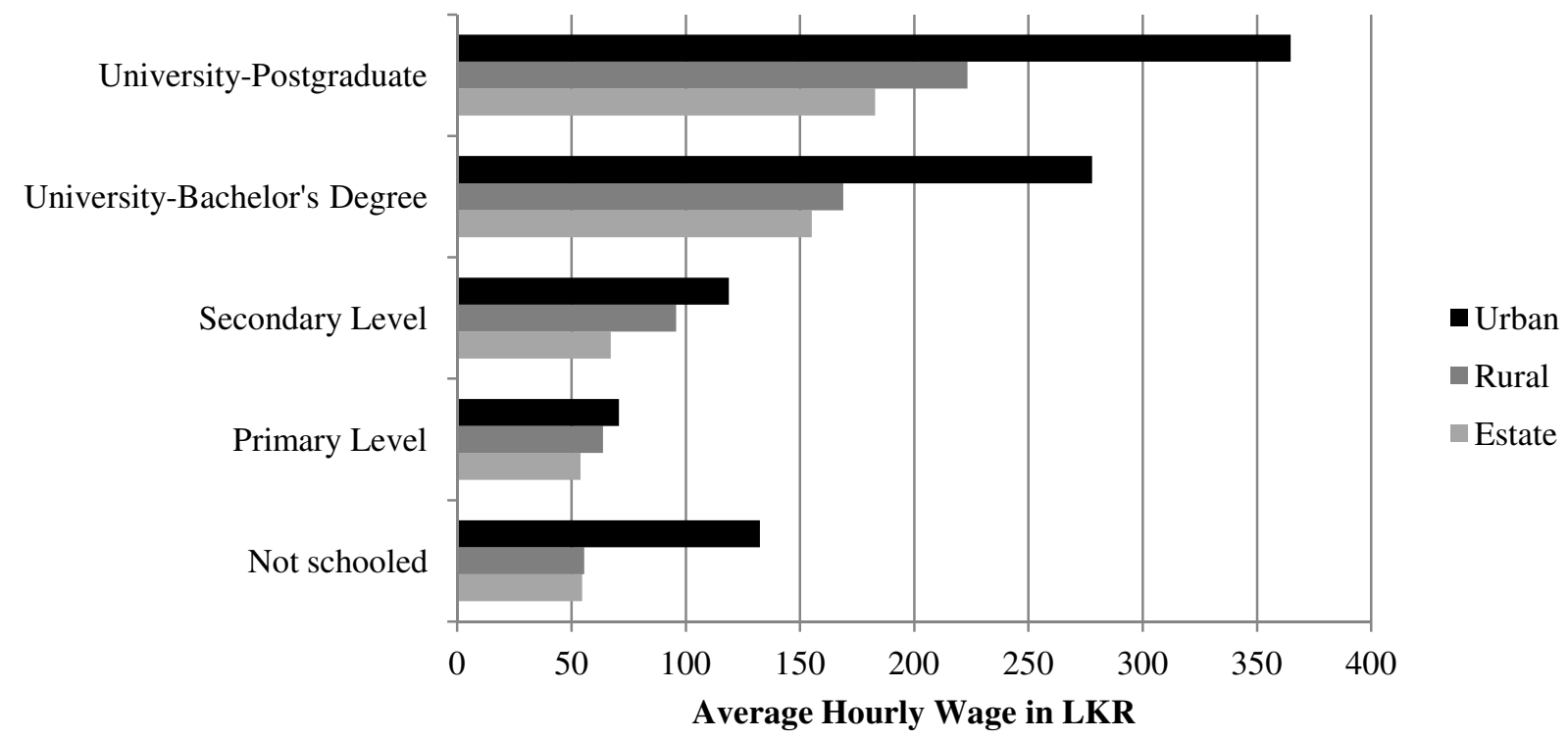

Source: Own calculation based on Sri Lanka Labour Force Survey-2013

Note: Hourly wage rate differentials across different levels of education are statistically significant at 5\% error level within each living sector and between three living sectors. 
Figure 03: Average Hourly Wage by Maximum Educational Attainment and Living Province

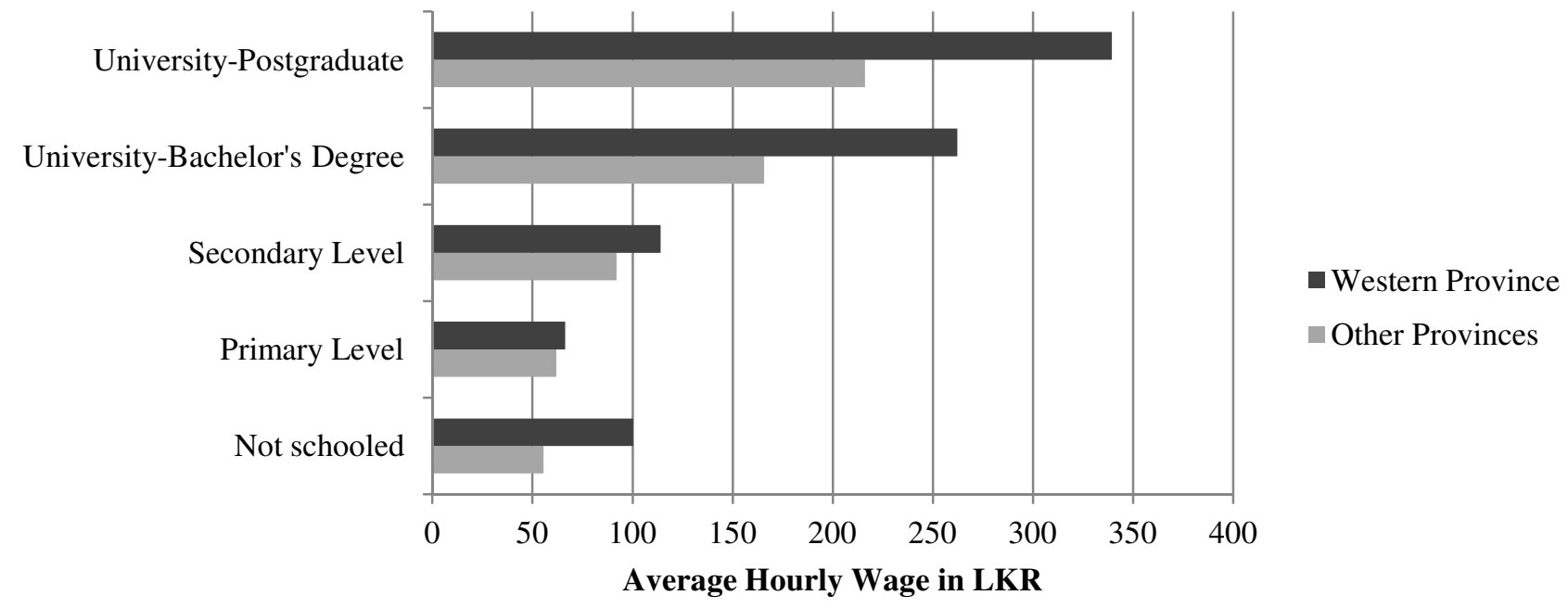

Source: Own calculation based on Sri Lanka Labour Force Survey-2013

Note: Hourly wage rate differentials across different levels of education are statistically significant at 5\% error level within each provincial group and between two provincial groups.

Figure 04: Average Hourly Wage by Maximum Educational Attainment and Employment Sector

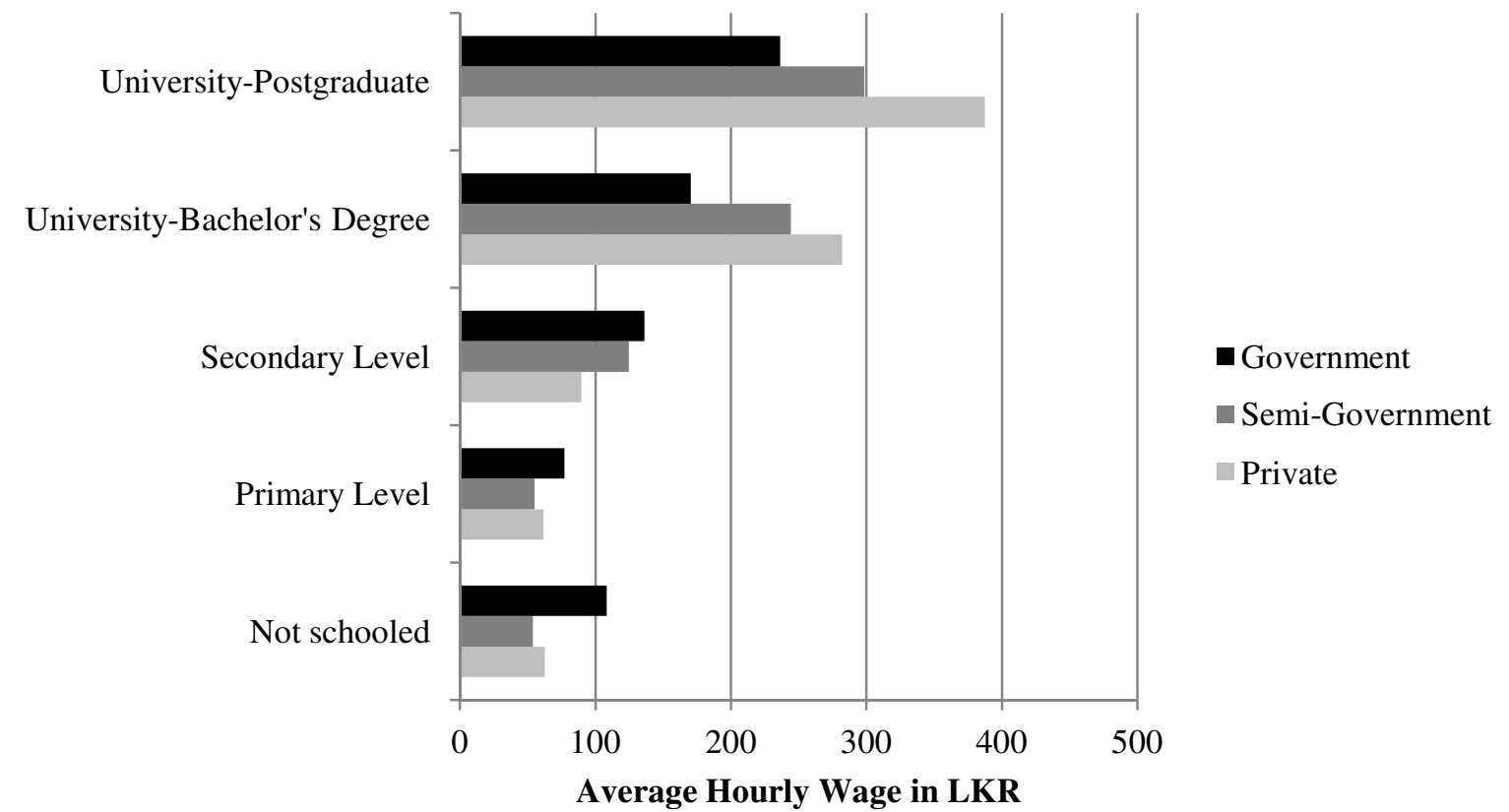

Source: Own calculation based on Sri Lanka Labour Force Survey-2013

Note: Hourly wage rate differentials across different levels of education are statistically significant at 5\% error level within each employment sector and between three employment sectors. 
Figure 05: Quantile and OLS estimates of the impact of covariates on wage income after accounting for the sample-selection bias
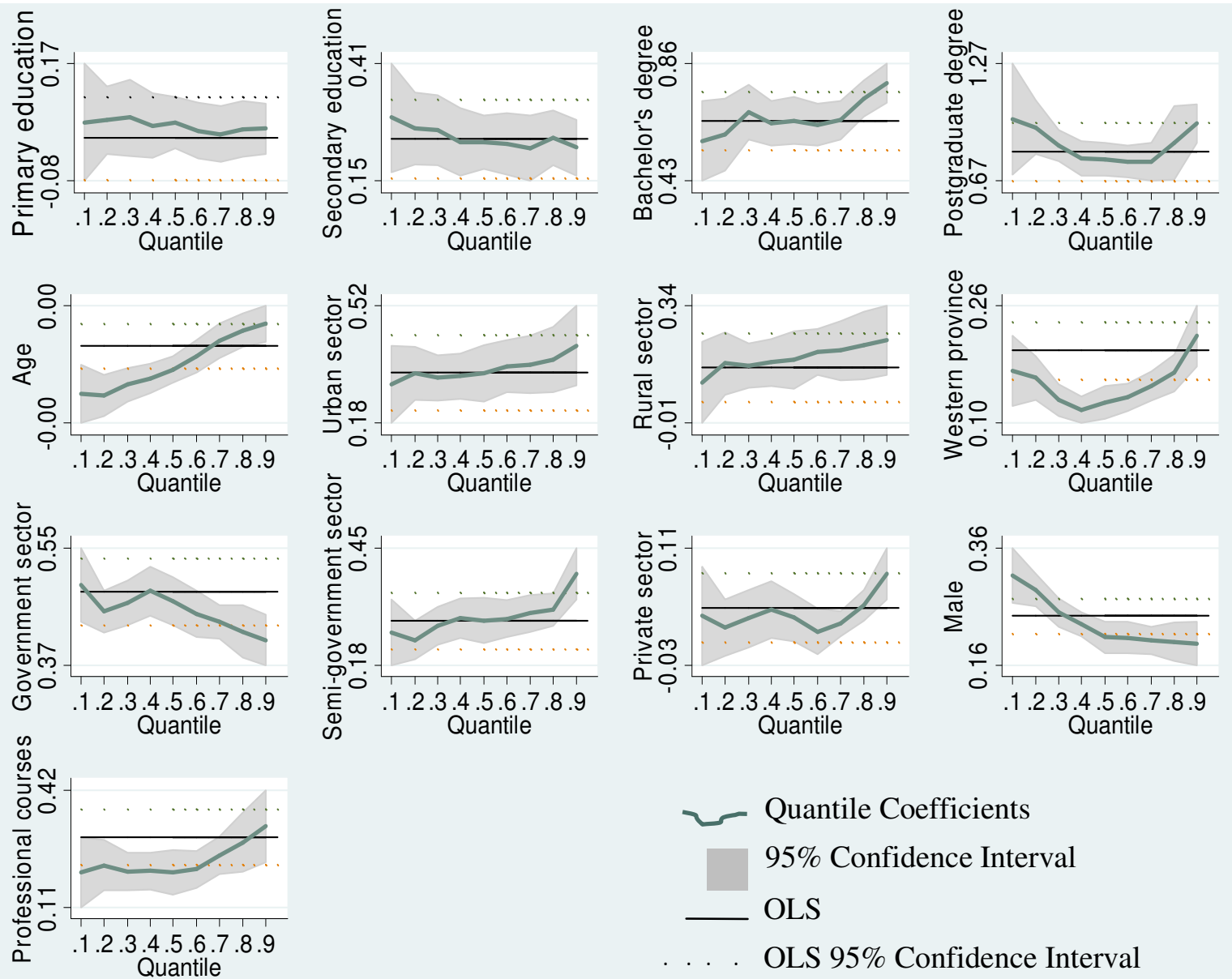

Source: Own calculation based on Sri Lanka Labour Force Survey-2013 
Table 01: Demographic profile of sample

\begin{tabular}{|c|c|c|}
\hline Panel A: Sample by discrete variables & $\overline{\mathrm{N}}$ & Frequency $(\%)$ \\
\hline \multicolumn{3}{|l|}{ Employment status } \\
\hline Wage employees & 16,525 & 28.15 \\
\hline All other categories & 42,185 & 71.85 \\
\hline \multicolumn{3}{|l|}{ Highest educational attainment } \\
\hline Not schooled (Reference*) & 2,304 & 3.92 \\
\hline Primary education & 9,146 & 15.58 \\
\hline Secondary education & 45,647 & 77.75 \\
\hline Bachelor's degree & 1,251 & 2.13 \\
\hline Postgraduate degree & 362 & 0.62 \\
\hline \multicolumn{3}{|l|}{ Living sector } \\
\hline Urban & 9,729 & 16.57 \\
\hline Rural & 46,724 & 79.58 \\
\hline Estate (Reference) & 2,257 & 3.85 \\
\hline \multicolumn{3}{|l|}{ Employment sector (only for wage employees) } \\
\hline Government sector & 3,234 & 19.57 \\
\hline Semi-government sector & 1,221 & 7.39 \\
\hline Private sector & 9,194 & 55.64 \\
\hline Informal sector (Reference) & 2,876 & 17.40 \\
\hline \multicolumn{3}{|l|}{ Province } \\
\hline Western & 14,363 & 24.46 \\
\hline Non-Western (Reference) & 44,347 & 75.54 \\
\hline \multicolumn{3}{|l|}{ Gender } \\
\hline Male & 27,100 & 46.16 \\
\hline Female (Reference) & 31,610 & 53.84 \\
\hline \multicolumn{3}{|l|}{ Religion } \\
\hline Buddhists & 40,254 & 68.56 \\
\hline Hindu & 8,514 & 14.50 \\
\hline Muslim & 5,368 & 9.14 \\
\hline Others (Reference) & 4,574 & 7.80 \\
\hline \multicolumn{3}{|l|}{ Marital status } \\
\hline Married & 38,405 & 65.41 \\
\hline Non-married (Reference) & 20,305 & 34.59 \\
\hline \multicolumn{3}{|l|}{ Birth quarter } \\
\hline Q1 & 15,124 & 25.76 \\
\hline Q2 & 15,624 & 26.62 \\
\hline Q3 & 13,546 & 23.07 \\
\hline Q4 (Reference) & 14,415 & 24.55 \\
\hline \multicolumn{3}{|l|}{ Professional courses } \\
\hline Yes & 5,963 & 10.16 \\
\hline No (Reference) & 52,747 & 89.84 \\
\hline Panel B: Summary statistics of continuous variables & Mean & STD \\
\hline Hourly wage (LKR) & 100.20 & 110.16 \\
\hline Age (Years) & 42 & 18 \\
\hline Years of schooling & 10 & 04 \\
\hline Family effect & 08 & 03 \\
\hline
\end{tabular}

Source: Own calculations based on Sri Lanka Labor Force Survey, 2013

*Note: "Reference" indicates the reference (base) category of each variable used in subsequent analyses. 
Table 02: OLS and 2SLS estimates of the impact of covariates on hourly wage rate

\begin{tabular}{|c|c|c|c|}
\hline & $\begin{array}{c}\text { OLS } \\
\text { Equation } 01\end{array}$ & $\begin{array}{c}\text { OLS } \\
\text { Equation } 02\end{array}$ & $\begin{array}{c}2 \text { SLS } \\
\text { IV Regression }\end{array}$ \\
\hline Years of schooling & $\begin{array}{l}0.0544 * * * \\
(0.0026)\end{array}$ & & $\begin{array}{l}0.0780 * * * \\
(0.0073)\end{array}$ \\
\hline Primary education & & $\begin{array}{l}0.0146 \\
(0.0423)\end{array}$ & \\
\hline Secondary education & & $\begin{array}{l}0.2441 * * * \\
(0.0398)\end{array}$ & \\
\hline Bachelor's degree & & $\begin{array}{l}0.6497 * * * \\
(0.0546)\end{array}$ & \\
\hline Postgraduate degree & & $\begin{array}{l}0.8207 * * * \\
(0.0863)\end{array}$ & \\
\hline Experience & $\begin{array}{l}0.0033 * * * \\
(0.0007)\end{array}$ & $\begin{array}{l}0.0012 * \\
(0.0006)\end{array}$ & $\begin{array}{l}0.0051 * * * \\
(0.0008)\end{array}$ \\
\hline Experience $^{2}$ & $\begin{array}{l}-0.0005 * * * \\
(0.0000)\end{array}$ & $\begin{array}{l}-0.0005^{* * * *} \\
(0.0000)\end{array}$ & $\begin{array}{l}-0.0005 * * * \\
(0.0000)\end{array}$ \\
\hline Urban sector & $\begin{array}{l}0.2011 * * * \\
(0.0350)\end{array}$ & $\begin{array}{l}0.3213 * * * \\
(0.0351)\end{array}$ & $\begin{array}{l}0.0984 * * \\
(0.0470)\end{array}$ \\
\hline Rural sector & $\begin{array}{l}0.0443 \\
(0.0312)\end{array}$ & $\begin{array}{l}0.1493 * * * \\
(0.0314)\end{array}$ & $\begin{array}{l}-0.0431 \\
(0.0403)\end{array}$ \\
\hline Western province & $\begin{array}{l}0.1803 * * * \\
(0.0157)\end{array}$ & $\begin{array}{l}0.2005^{* * * *} \\
(0.0159)\end{array}$ & $\begin{array}{l}0.1592 * * * \\
(0.0184)\end{array}$ \\
\hline Government sector & $\begin{array}{l}0.3732 * * * \\
(0.0262)\end{array}$ & $\begin{array}{l}0.4815^{* * * *} \\
(0.0250)\end{array}$ & $\begin{array}{l}0.2556^{* * *} \\
(0.0440)\end{array}$ \\
\hline Semi-government sector & $\begin{array}{l}0.1729 * * * \\
(0.0356)\end{array}$ & $\begin{array}{l}0.2790 * * * \\
(0.0354)\end{array}$ & $\begin{array}{l}0.0984 * * \\
(0.0399)\end{array}$ \\
\hline Private sector & $\begin{array}{l}-0.0134 \\
(0.0211)\end{array}$ & $\begin{array}{l}0.0351 * \\
(0.0211)\end{array}$ & $\begin{array}{l}-0.0465^{* *} \\
(0.0228)\end{array}$ \\
\hline Gender: Male & $\begin{array}{l}0.2490 * * * \\
(0.0156)\end{array}$ & $\begin{array}{l}0.2454 * * * \\
(0.0160)\end{array}$ & $\begin{array}{l}0.2538 * * * \\
(0.0156)\end{array}$ \\
\hline Professional courses & $\begin{array}{l}0.2310 * * * \\
(0.0186)\end{array}$ & $\begin{array}{l}0.2989 * * * \\
(0.0182)\end{array}$ & $\begin{array}{l}0.1841 * * * \\
(0.0250)\end{array}$ \\
\hline Observations & 16,525 & 16,525 & 16,525 \\
\hline R-squared & 0.1679 & 0.1576 & 0.1627 \\
\hline Wu-Hausman test & & & $11.7585^{* * *}$ \\
\hline $\begin{array}{l}P \text {-value } \\
\text { Sargan score }\end{array}$ & & & $\begin{array}{l}0.0006 \\
3.5560\end{array}$ \\
\hline$P$-value & & & 0.3136 \\
\hline F-statistics: First-stage re & ression & & $474.055^{* * *}$ \\
\hline Cragg and Donald (1993) & minimum Eige & value & 474.055 \\
\hline Critical value at $5 \%$ 2SL & relative bias & & 16.85 \\
\hline
\end{tabular}

Source: Own calculations based on Sri Lanka Labor Force Survey, 2013

Note: Robust standard errors are in parentheses. $* * *, * * *$, and $*$ indicate statistical significance at $1 \%, 5 \%$, and $10 \%$ error levels, respectively. 
Table 03: Heckman estimates of the impact of covariates on hourly wage rate

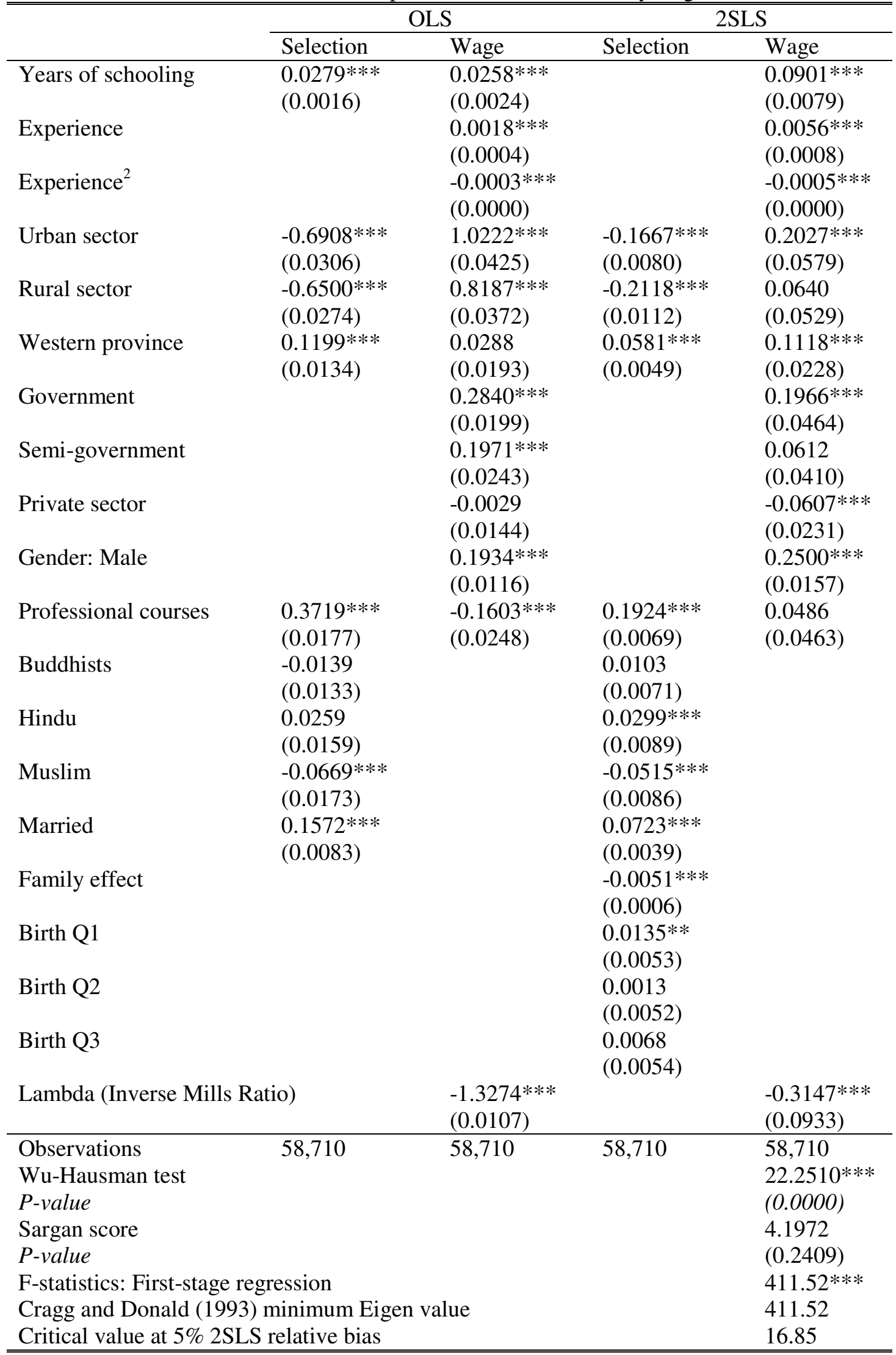

Source: Own calculations based on Sri Lanka Labor Force Survey, 2013

Note: Robust standard errors are in parentheses. $* * *, * * *$, and $*$ indicate statistical significance at $1 \%, 5 \%$, and $10 \%$ error levels, respectively 
